\title{
Antifungal and Antiproliferative Protein from Cicer arietinum: A Bioactive Compound against Emerging Pathogens
}

\author{
Suresh Kumar, ${ }^{1}$ Vaishali Kapoor, ${ }^{2}$ Kamaldeep Gill,, ${ }^{1}$ Kusum Singh, \\ Immaculata Xess, ${ }^{3}$ Satya N. Das, ${ }^{2}$ and Sharmistha Dey ${ }^{1}$ \\ ${ }^{1}$ Department of Biophysics, All India Institute of Medical Sciences, New Delhi 110029, India \\ ${ }^{2}$ Department of Biotechnology, All India Institute of Medical Sciences, New Delhi 110029, India \\ ${ }^{3}$ Department of Microbiology, All India Institute of Medical Sciences, New Delhi 110029, India \\ Correspondence should be addressed to Sharmistha Dey; sharmistha_d@hotmail.com
}

Received 21 January 2014; Revised 9 April 2014; Accepted 23 April 2014; Published 14 May 2014

Academic Editor: Vasilis P. Valdramidis

Copyright (C) 2014 Suresh Kumar et al. This is an open access article distributed under the Creative Commons Attribution License, which permits unrestricted use, distribution, and reproduction in any medium, provided the original work is properly cited.

\begin{abstract}
The emergence of epidemic fungal pathogenic resistance to current antifungal drugs has increased the interest in developing alternative antibiotics from natural sources. Cicer arietinum is well known for its medicinal properties. The aim of this work was to isolate antimicrobial proteins from Cicer arietinum. An antifungal protein, C-25, was isolated from Cicer arietinum and purified by gel filtration. C-25 protein was tested using agar diffusion method against human pathogenic fungi of ATCC strains and against clinical isolates of Candida krusei, Candida tropicalis, and Candida parapsilosis, and MIC values determined were varied from 1.56 to $12.5 \mu \mathrm{g} / \mathrm{mL}$. The SEM study demonstrated that C-25 induces the bleb-like surface changes, irregular cell surface, and cell wall disruption of the fungi at different time intervals. Cytotoxic activity was studied on oral cancer cells and normal cells. It also inhibits the growth of fungal strains which are resistant to fluconazole. It reduced the cell proliferation of human oral carcinoma cells at the concentration of $37.5 \mu \mathrm{g} / \mathrm{mL}\left(\mathrm{IC}_{50}\right.$ ) and no toxic effect was found on normal human peripheral blood mononuclear cells even at higher concentration of $600 \mu \mathrm{g} / \mathrm{mL}$. It can be concluded that C-25 can be considered as an effective antimycotic as well as antiproliferative agent against human oral cancer cells.
\end{abstract}

\section{Introduction}

The major healthcare problem is the antibiotic resistance which arises the lack of effective therapeutics for microbial infection. During the past few years a wide spectrum of plant antimicrobial proteins has been identified and has enhanced the activity in low duration to prevent the development of resistant by microbes.

There are several classes of proteins having antimicrobial properties which include thionins, lipid transfer proteins, plant defensins, chitinases, glucanases, $2 S$ albumins, ribosome inactivating proteins, and lectin $[1,2]$. Lectins are proteins or glycoproteins of a ubiquitous distribution in nature, which have at least one carbohydrate or derivative binding site without catalytic function or immunological characteristics. They have the unique ability to recognize and bind reversibly to specific carbohydrate ligands without any chemical modification which distinguishes lectins from other carbohydrate binding proteins and enzymes and makes them invaluable tools in biomedical and glycoconjugate research. In plant, lectin plays an important role in the defence against harmful fungi, insects, and bacteria. Several lectins have been found to possess anticancer properties in human case studies, where they are used as therapeutic agents binding to the cancer cell membrane or their receptors causing cytotoxicity, apoptosis, and inhibition of tumor growth $[3,4]$.

Cicer arietinum (chickpea) is a legume and belongs to the Fabaceae family. It contains 75\% fibres and low fat protein. It has been reported that the use of Cicer arietinum helps in diabetes and cardiovascular diseases and in some cancers. Some lectins having hemagglutination activity were isolated earlier from Cicer arietinum [5]. This study focused on isolation and characterization of a lectin protein possessing medicinal properties from the seeds of Cicer arietinum. 


\section{Methods}

2.1. Ethics. The Ethics Committee of All India Institute of Medical Sciences (AIIMS), New Delhi, India, approved the study protocol (IEC/NP-374/2013) and informed consent was obtained.

2.2. Isolation and Purification of Protein from Cicer arietinum. Cicer arietinum seeds were soaked, homogenized in $10 \mathrm{mM}$ Tris-Cl buffer ( $\mathrm{pH} 7.2$ ), and centrifuged at 13,000 $\times \mathrm{g}$ for $30 \mathrm{~min}$. at $4^{\circ} \mathrm{C}$. The resulting crude extract was treated with ammonium sulphate with $30 \%$ saturation under cold condition and the precipitant was centrifuged at $13,000 \times \mathrm{g}$ for $30 \mathrm{~min}$. at $4^{\circ} \mathrm{C}$. The salt was removed from the resultant supernatant by dialysis membrane $(10 \mathrm{kDa})$ in the same buffer.

The dialysed sample was loaded onto Sephadex G-100 gel filtration column preequilibrated with $10 \mathrm{mM}$ Tris- $\mathrm{HCl}$ (pH7.2) and $150 \mathrm{mM} \mathrm{NaCl}$. The proteins were eluted using the same buffer and simultaneously monitored at $280 \mathrm{~nm}$. Each fraction was tested for antimicrobial activity. One fraction showed inhibition activity against fungi and it was characterized further.

\subsection{Characterization of the Purified Protein}

2.3.1. Molecular Mass Determination. The concentration of proteins was estimated by BCA Protein Assay Kit (Thermo Scientific, Rockford, USA) using Bovine serum albumin as a standard. The $12 \%$ SDS-PAGE of the protein was carried out using Laemmli system of buffers [6] in the presence and absence of 2-mercaptoethanol. The electrophoretic mobility of the protein and protein marker were compared to determine the molecular weight of the protein.

2.3.2. N-Terminal Amino Acid Sequence Analysis. The Nterminal sequence analysis of the C-25 protein was done by Edman degradation on a Procise Protein Sequencer (Applied Biosystems). The database was searched for other antifungal proteins with similar sequences using BLAST (http://www. ncbi.nlm.nih.gov/BLAST).

2.3.3. Hemagglutination Activity and Sugar Inhibition Assays. Hemagglutination studies of the purified protein were carried out using human erythrocytes in a 96-well microtiter plate. $50 \mu \mathrm{L}$ of purified protein solution $(0.8 \mathrm{mg} / \mathrm{mL})$ was placed in the first well and twofold serially diluted into the successive wells with phosphate buffered saline, $\mathrm{pH}$ 7.4. Then, $50 \mu \mathrm{L}$ of $4 \%$ human erythrocyte suspension was added to all the wells. Hemagglutination was visualized in the plate after $1 \mathrm{~h}$ of incubation at $37^{\circ} \mathrm{C}$.

Hemagglutination inhibition assays [7] with the purified protein were performed by placing $50 \mu \mathrm{L}$ of different sugar solutions $(40 \mathrm{mM})$ including inulin, D-mannose, Dglucose, $\mathrm{D}$-ribose, $\mathrm{N}$-acetyl-D-galactosamine, and melibiose in respective wells of the plate and serially twofold diluted. Then, $50 \mu \mathrm{L}$ of the purified protein $(0.8 \mathrm{mg} / \mathrm{mL})$ was added to each well and incubated for $30 \mathrm{~min}$. at $37^{\circ} \mathrm{C}$. Later, $50 \mu \mathrm{L}$ of $4 \%$ erythrocyte suspension was added and the plate was incubated for $1 \mathrm{~h}$ at $37^{\circ} \mathrm{C}$. Hemagglutination inhibition titre was scored visually.

2.3.4. Detection of Antifungal Activity. Antifungal activity of the purified protein was tested using agar diffusion method against human pathogenic fungi such as Candida parapsilosis ATCC22019, Candida krusei ATCC6258, and Candida tropicalis ATCC13803. All Candida species were grown overnight on Sabouraud's dextrose agar plates. Each colony was inoculated in $5 \mathrm{~mL}$ of $0.9 \%(\mathrm{w} / \mathrm{v})$ normal saline to make inoculum suspension adjusted with $0.5 \mathrm{Mc}$ Farland standard solutions and the cell suspension was spread by sterile cotton swab over the Mueller Hinton agar (MHA) plates under aseptic conditions. The wells were bored with a borer and $0.1 \mathrm{~mL}$ of purified protein $(200 \mu \mathrm{g} / \mathrm{mL})$ was added to respective wells. Fluconazole disc $(25 \mathrm{mcg})$ was used as positive control. The plates were incubated at $35^{\circ} \mathrm{C}$ for $24 \mathrm{~h}$ and the zone of inhibition was observed.

2.3.5. Determination of Minimum Inhibitory Concentration (MIC). The MIC was performed on Candida parapsilosis ATCC22019, Candida krusei ATCC6258, Candida tropicalis ATCC13803, and clinical isolates of the same strains from 45 patients with Candida infection. The patient samples were taken from Department of Microbiology, AIIMS. The MIC was determined according to the CLSI (Clinical and Laboratory Standards Institute) guidelines [8]. Pure colonies of Candida species were suspended in $5 \mathrm{~mL}$ of sterilized saline $(0.9 \% \mathrm{w} / \mathrm{v})$ to a concentration of $5 \times 10^{6} \mathrm{CFU} / \mathrm{mL}$ as matched with $0.5 \mathrm{McF}$ arland Standard solutions. $100 \mu \mathrm{L}$ of purified protein $(200 \mu \mathrm{g} / \mathrm{mL})$ solution was added and twofold serially diluted using RPMI-1640 media. $100 \mu \mathrm{L}$ of each final inoculum suspension $\left(2.5 \times 10^{3} \mathrm{CFU} / \mathrm{mL}\right)$ was added to the respective wells and the plates were incubated at $35^{\circ} \mathrm{C}$ for $24 \mathrm{~h}$. The fungal strains C. krusei and C. parapsilosis without treatment and uninoculated RPMI-1640 media were used as growth and media control, respectively. The MIC was calculated as the lowest concentration at which cell growth was inhibited. Fluconazole drug was used as a positive control. The experiment was performed in triplicate.

2.3.6. Scanning Electron Microscopic (SEM) Studies. The inoculated Candida krusei ATCC6258 was incubated in MHB (Mueller Hilton broth) media at $35^{\circ} \mathrm{C}$ overnight, which was further incubated for another $2 \mathrm{~h}$ at $35^{\circ} \mathrm{C}$ in fresh media for exponential growth phase. After washing with PBS, cells were suspended in $10 \mathrm{mM}$ phosphate buffer $(\mathrm{pH} 7.4)$ at a final concentration of $1 \times 10^{6} \mathrm{CFU} / \mathrm{mL}$. The protein at concentrations of $12.5 \mu \mathrm{g} / \mathrm{mL}$ ( $2 \mathrm{xMIC}$ ) was added to the cell suspension and was incubated at different time intervals at $35^{\circ} \mathrm{C}$. High concentration of test sample is chosen in order to achieve killing of a high number of yeast cells [9]. The cells were prepared for SEM study by treatment with $1 \%$ osmium tetroxide for $1 \mathrm{~h}$ at $4^{\circ} \mathrm{C}$ [10]. The cells were visualized under Electron Microscope (LEO, Cambridge, UK). Images were digitally acquired by using a CCD camera attached to the microscope. 
2.3.7. Determination of Cytotoxicity. Cytotoxic effect of protein was analyzed using oral carcinoma cell line (KB cells) using MTT dye reduction assay [11]. Briefly, $5 \times$ $10^{3}$ cells $/ 100 \mu \mathrm{L}$ media (EMEM) were seeded in 96-well plates $24 \mathrm{~h}$ before the experiment. The cells were then incubated with different concentrations $(9-600 \mu \mathrm{g} / \mathrm{mL}$ in EMEM) of protein for $48 \mathrm{~h} .10 \mu \mathrm{L}$ of MTT solution $(10 \mathrm{mg} / \mathrm{mL}$ in PBS) was then added to each well and plates were further incubated for $3 \mathrm{~h}$ at $37^{\circ} \mathrm{C}$. The formazan crystals formed were dissolved by adding $100 \mu \mathrm{L}$ of DMSO. The cells were treated with $1 \%$ Tris- $\mathrm{HCl}$ (same concentration as used for the solvent of C25) which was then subtracted from all the cytotoxic values. Absorbance was measured by a microplate reader at $570 \mathrm{~nm}$ and the reference filter $650 \mathrm{~nm}$ was used. The data obtained were presented as percentage of cell survival in the bestfit (linear) dose response curves. The $\mathrm{IC}_{50}$ value at $95 \%$ confidence interval was calculated. Each concentration was used in triplicate.

To examine the cytotoxicity effect of this protein on PBMCs, peripheral blood mononuclear cells (PBMCs) were isolated by density gradient centrifugation using Histopaque1077 (Sigma-Aldrich, USA) as per the standard protocol [12] from healthy human blood and collected in heparinized tubes and diluted 1:2 with fresh sterile phosphate-buffered saline (PBS). The proliferation analysis of C-25 was performed by MTT assay as described above.

2.3.8. Kinetic Analysis with $p 38 \alpha$ MAP Kinase. The kinetic analysis of protein was done with p38 $\alpha$ MAP kinase as this signaling molecule was found to be overexpressed in oral cancer [13]. Hence, binding study of protein was performed with recombinant p38 $\alpha$ MAP kinase (mitogen activated protein kinase) using both ELISA and BIAcore to ensure the anticancer activity.

(1) By ELISA. The assay was performed in 96-well microtitre plate coated with ATF- 2 protein at $37^{\circ} \mathrm{C} .12 \mu \mathrm{g}$ of $\mathrm{p} 38 \alpha$ protein was incubated with six different concentrations of protein ( 1 , $2.5,5,10,15,20$, and $25 \mu \mathrm{M})$ for $1.5 \mathrm{~h}$. The kinase mixture (purified p38 $\alpha$ incubated with C-25 protein, $50 \mathrm{mM}$ Tris, $\mathrm{pH}$ 7.5, $10 \mathrm{mM} \mathrm{MgCl}_{2}, 10 \mathrm{mM} \beta$-glycerophosphate, $100 \mu \mathrm{g} / \mathrm{mL}$ BSA, $1 \mathrm{mM}$ DTT, $0.1 \mathrm{mM} \mathrm{Na}_{3} \mathrm{VO}_{4}$, and $100 \mu \mathrm{M}$ ATP) was added and incubated for $1 \mathrm{~h}$ at $37^{\circ} \mathrm{C}$. After washing, the plates were incubated with anti-phospho ATF-2 antibody $(1: 400)$ (Biovision) for $1 \mathrm{~h}$ at $37^{\circ} \mathrm{C}$ and subsequently with alkaline phosphates conjugated goat anti-rabbit IgG (1:4000) (Chemicon) for $1 \mathrm{~h}$ at $37^{\circ} \mathrm{C}$. Finally, the chromogenic substrate solution 4-nitrophenyl phosphate (4-NPP) in $0.1 \mathrm{M}$ Tris- $\mathrm{HCl}, \mathrm{pH}$ 8.1, and $0.01 \% \mathrm{MgCl}_{2}$ (Cayman Chemical Company, USA) was added for $1.5 \mathrm{~h}$ at $37^{\circ} \mathrm{C}$ and the formation of nitrophenolate was measured at $405 \mathrm{~nm}$ which analyzed the extent of phosphorylation of ATF-2. The assay was performed in triplicate for each concentration and mean \pm $\mathrm{SD}$ values were used to calculate the $\mathrm{IC}_{50}$ value.

(2) By Surface Plasmon Resonance (SPR). The His-tagged recombinant $\mathrm{p} 38 \alpha$ protein was immobilized on the NTA sensor chip via $\mathrm{Ni}^{2+} / \mathrm{NTA}$ chelation at $25^{\circ} \mathrm{C}$ in BIAcore2000 (GE Healthcare, Sweden). The surface was first activated with $\mathrm{Ni}^{2+}$ forming a chelating complex with NTA which further binds with His-tag of recombinant protein. $2 \mathrm{mM}$ $\mathrm{NiCl}_{2}$ solution was passed at a flow rate of $5 \mu \mathrm{L} / \mathrm{min}$. One flow cell was used as a reference cell and, on the other, $20 \mu \mathrm{L}$ of His-tagged p38 $\alpha(9 \mathrm{mg} / \mathrm{mL})$ was injected at a flow rate of $5 \mu \mathrm{L} / \mathrm{min}$. for immobilization. The binding parameters of the C-25 were measured by injecting three different concentrations $\left(4.6 \times 10^{-6} \mathrm{M}, 9.2 \times 10^{-6} \mathrm{M}\right.$, and $\left.13.8 \times 10^{-6} \mathrm{M}\right)$ over the immobilized protein. BIAevaluation 3.0 software was used to determine the dissociation constant (KD) of the inhibitory protein.

\section{Results}

3.1. Purification and Molecular Characterization. Crude protein extract from Cicer arietinum was subjected to ammonium sulphate precipitation to remove unwanted proteins. Three peaks were obtained after gel filtration with Sephadex G-100 column (Figure 1(a)). In SDS-PAGE of these fractions, the third peak showed a single band corresponding to molecular mass of $25 \mathrm{kDa}$ named as C-25. The antifungal activity was found in peak 3 fractions (Figure $1(\mathrm{~b})$ ). Both Lane 2 and Lane 3 showed a single band of C-25 in the presence and absence of mercaptoethanol, respectively, which revealed the protein to be a monomer (Figure 1(c)).

3.2. N-Terminal Amino Acid Sequence Analysis. N-terminal amino acid sequence of the purified C-25 from Cicer arietinum is shown in Table 1 and it was compared with other antifungal proteins using Blast from NCBI website. This protein exhibited $100 \%$ sequence similarity of 10 amino acid residues with sequence of lectin from other plant sources.

3.3. Hemagglutinating Activity and Inhibition Assay. C-25 protein from Cicer arietinum readily agglutinated human erythrocytes showing the hemagglutination activity. Hemagglutination-inhibition assay was performed with C-25 to investigate its sugar specificity. The results showed that agglutination activity of C-25 was inhibited strongly by $\mathrm{N}$ acetyl-D-galactosamine and not by any other sugar moieties, indicating that the acetamido moiety of this sugar might have interacted with C-25. Agglutination activity of C-25 was inhibited by $20 \mathrm{mM}$ of N-acetyl-D-galactosamine (S1) indicating that C-25 specifically binds with N-acetyl-Dgalactosamine.

3.4. Assay of Antifungal Activity. The pure C-25 obtained from gel filtration was tested for antifungal activity against $C$. parapsilosis, C. krusei, and C. tropicalis by agar well diffusion method using fluconazole drug as a positive control. The zone of inhibition around the test sample was found in all the above mentioned Candida spp. (Figures 2(a), 2(b), and 2(c)). The MIC values of a C-25 against the above mentioned fungi and clinical isolates of Candida species from 45 patients were found to be varied from 1.56 to $12.5 \mu \mathrm{g} / \mathrm{mL}$ after $24 \mathrm{~h}$ incubation period. Among 45 clinical isolates strains, the MIC of $\leq 8 \mu \mathrm{g} / \mathrm{mL}$ are susceptible, 16 to $32 \mu \mathrm{g} / \mathrm{mL}$ are susceptible-dose dependent (SDD), and $\geq 64 \mu \mathrm{g} / \mathrm{mL}$ are resistant to fluconazole 


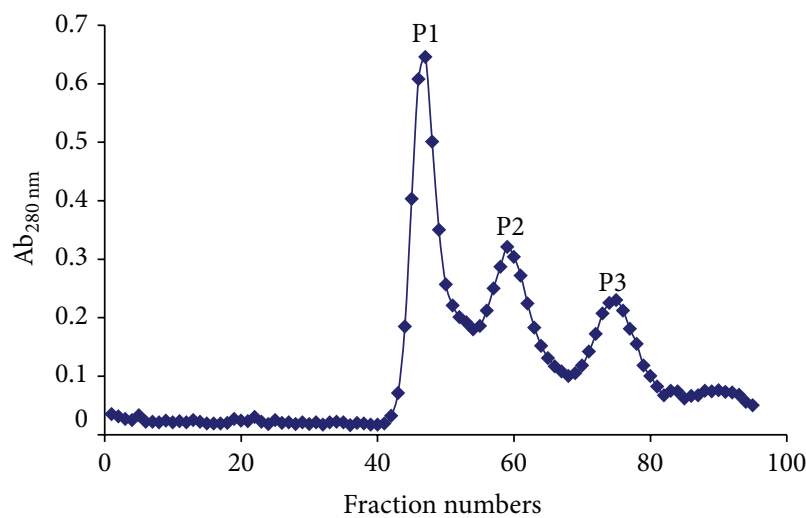

(a)

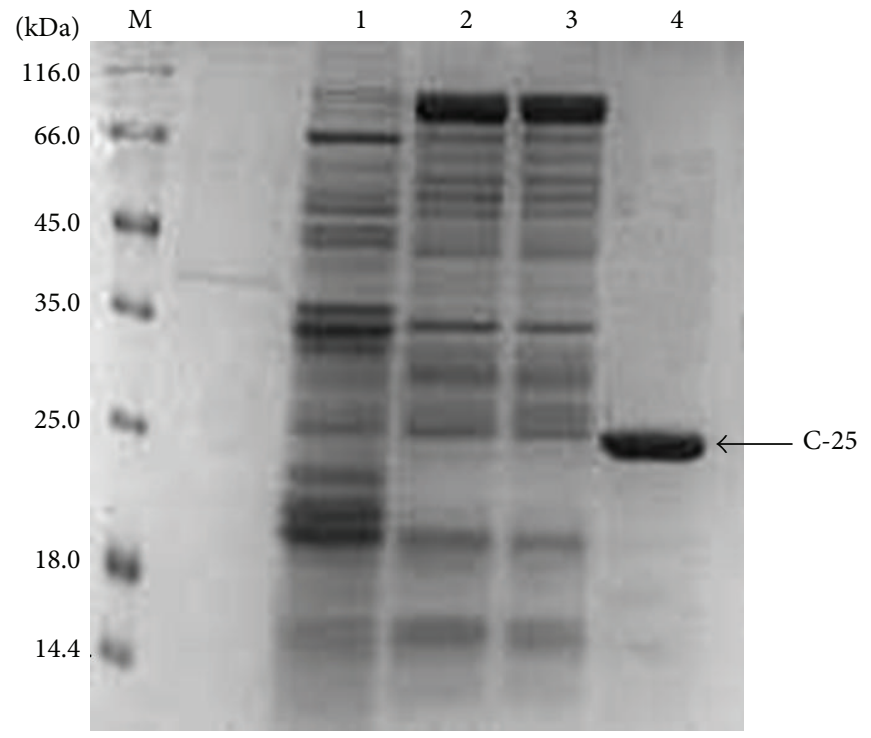

(b)

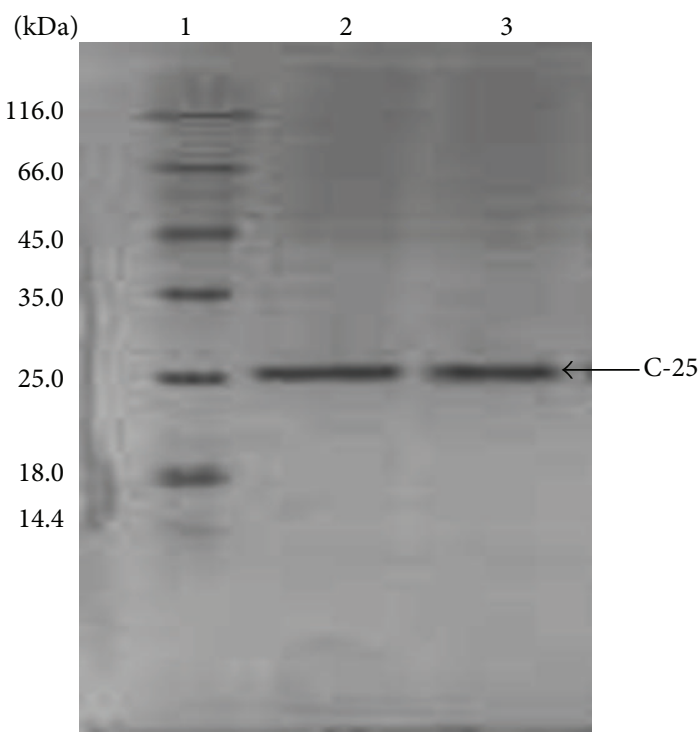

(c)

FIGURE 1: (a) Elution profile of C. arietinum protein crude extract from gel filtration on Sephadex G-100 column showing three peaks P1, P2, and P3. SDS-PAGE of protein fractions from gel filtration: (b) from left to right: Lane M is molecular mass marker, Lane 1 is eluent of P1, Lanes 2 and 3 are P2, and Lane 4 is P3 (C-25). (c) From left to right: Lane 1 is molecular mass marker, Lane 2 is P3 in the absence of mercaptoethanol under nonreducing conditions, Lane 3 is $\mathrm{P} 3$ in the presence of mercaptoethanol under reducing conditions.

TABLE 1: A comparison between N-terminal amino acids sequence of C-25 (TKTGYINAAF) and sequences of other proteins.

\begin{tabular}{lccc}
\hline Protein & Sequence & Accession number & \% identity \\
\hline C-25 protein & TKTGYINAAF & AGN33419 & 100 \\
Seed albumin 2 (Pisum sativum) & TKTGYINAAF & CAH55839.1 & 100 \\
Albumin 2 (Pisum sativum) & TKTGYINAAF & P08688.1 & 100 \\
Crystal structure of Ls24 (Lathyrus sativus) & TKPGYINAAF & Pdb:3LP9A & 90 \\
Crystal structure of albumin (Cicer arietinum) & TKTGYINAAF & $3 S 18$ & 100 \\
\hline
\end{tabular}




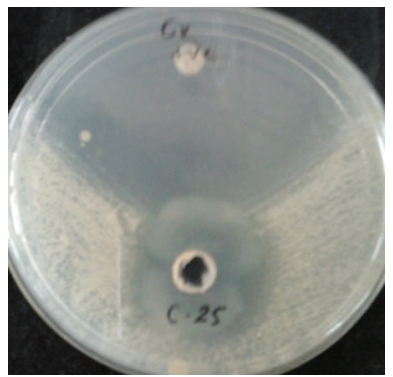

(a)

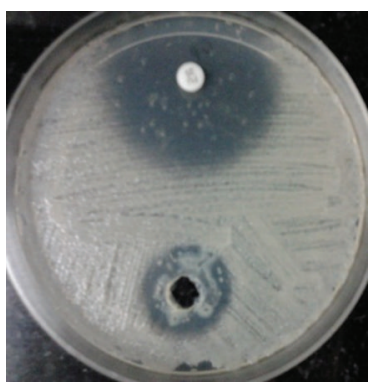

(b)

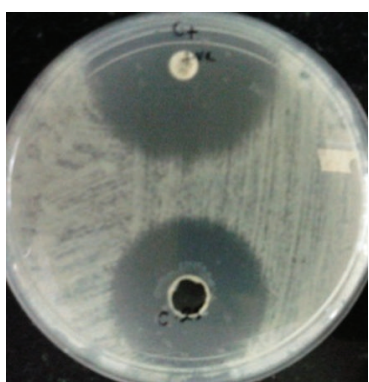

(c)

Figure 2: Antifungal assay of the C-25 protein showing zone of inhibition against (a) Candida krusei, (b) C. parapsilosis, and (c) C. tropicalis. Fluconazole disc was taken as positive control.

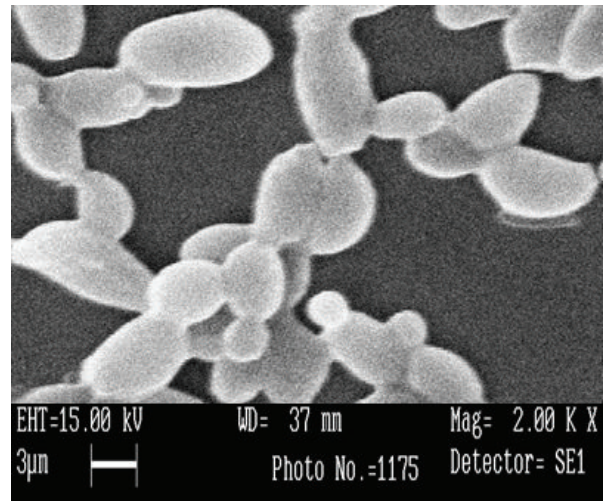

0 min

(a)

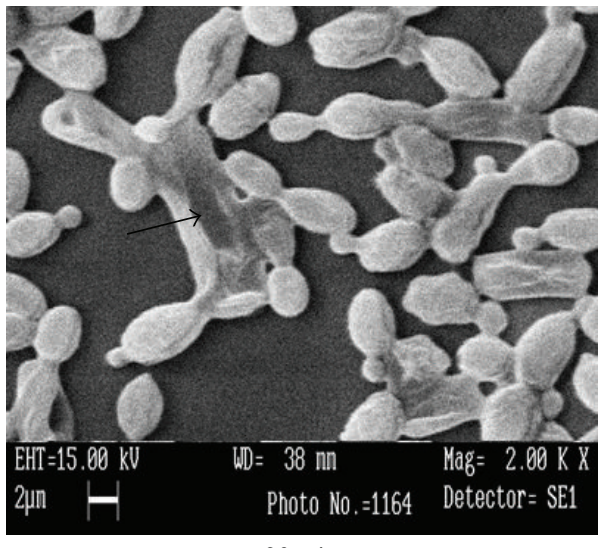

$30 \mathrm{~min}$

(c)

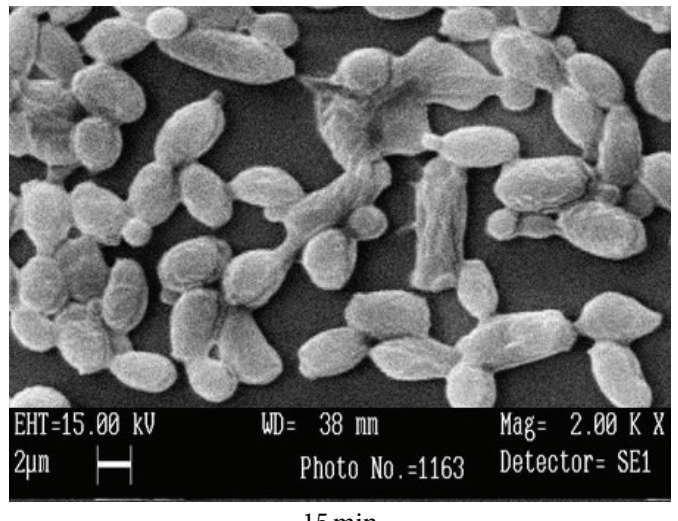

(b)

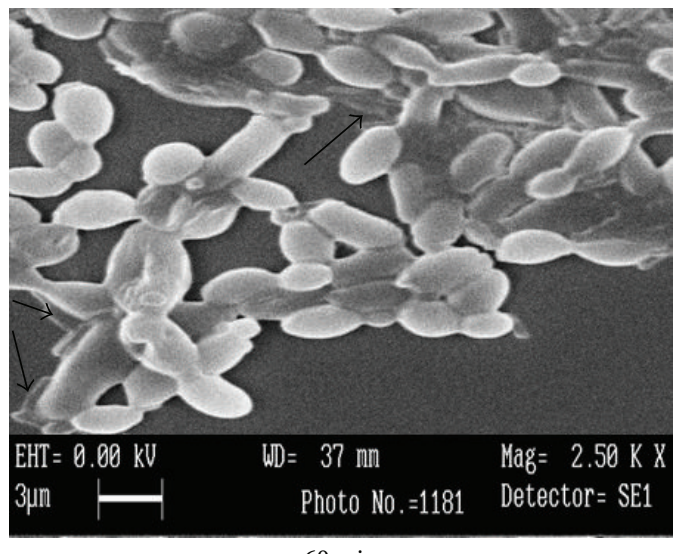

$60 \mathrm{~min}$

(d)

FIGURE 3: SEM study showing the cell wall disruption of Candida krusei treated with (a) $10 \mathrm{mM}$ PBS buffer (control) and (b), (c), and (d) $2 x M I C$ value $(12.5 \mu \mathrm{g} / \mathrm{mL})$ of C-25 protein at different time scales. The arrows indicate the cell wall disruption and cytoplasmic leakage.

as per CLSI document M27-A3, although C-25 was showing fungicidal activity on these strains (Table 2).

3.5. SEM Studies. To understand the mechanism of action of C-25 on the cell wall of fungi, SEM studies were performed with cells of C. krusei at different times of incubation with
$12.5 \mu \mathrm{g} / \mathrm{mL}$ of $\mathrm{C}-25$ and the changes in the morphology of cell wall of the C. krusei were examined. Figure 3(a) showed the morphology of the untreated cells (control). The effect of $12.5 \mu \mathrm{g} / \mathrm{mL}$ concentrations of C-25 showed different consequences on the cell wall. Figure 3(b) showed the bleb-like surface changes and cell shrinkage at $15 \mathrm{~min}$, and 
TABLE 2: MIC assay: ATCC and clinical isolates of Candida species from 45 patients treated with C-25 protein and fluconazole drug (control).

\begin{tabular}{|c|c|c|c|c|}
\hline $\begin{array}{l}\text { ATCC number/ } \\
\text { patient ID }\end{array}$ & Organism & Source & MIC $(\mu \mathrm{g} / \mathrm{mL})$ of fluconazole & $\operatorname{MIC}(\mu \mathrm{g} / \mathrm{mL})$ of C-25 \\
\hline 22019 (QC) & C. parapsilosis & ATCC & 1 & 6.25 \\
\hline $6258(\mathrm{QC})$ & C. krusei & ATCC & 16 & 6.25 \\
\hline 13803 (reference) & C. tropicalis & ATCC & 1 & 6.25 \\
\hline AID 19 & C. tropicalis & Blood & 2 & 6.25 \\
\hline AID 20 & C. tropicalis & Blood & 2 & 6.25 \\
\hline AID 21 & C. tropicalis & Blood & 2 & 6.25 \\
\hline AID 37 & C. parapsilosis & Blood & 1 & 6.25 \\
\hline AID 45 & C. tropicalis & Blood & 1 & 6.25 \\
\hline AID 47 & C. tropicalis & Blood & 1 & 6.25 \\
\hline 2549 & C. tropicalis & Blood & 0.5 & 1.56 \\
\hline 4347 & C. tropicalis & Blood & 1 & 3.125 \\
\hline 7004 & C. tropicalis & Blood & 0.5 & 1.56 \\
\hline 9097 & C. parapsilosis & Urine & 1 & 3.125 \\
\hline 9409 & C. parapsilosis & Urine & 1 & 3.125 \\
\hline 8995 & C. parapsilosis & Urine & 4 & 6.25 \\
\hline 8399 & C. tropicalis & Urine & 4 & 6.25 \\
\hline 8509 & C. tropicalis & Urine & 2 & 6.25 \\
\hline 8110 & C. tropicalis & Urine & 2 & 6.25 \\
\hline 9853 & C. tropicalis & Urine & 1 & 6.25 \\
\hline 9697 & C. tropicalis & Urine & 1 & 3.125 \\
\hline 9183 & C. tropicalis & Urine & 1 & 3.125 \\
\hline 9814 & C. tropicalis & Urine & 1 & 3.125 \\
\hline 9239 & C. tropicalis & Urine & 2 & 6.25 \\
\hline 9762 & C. tropicalis & Urine & 1 & 3.125 \\
\hline
\end{tabular}

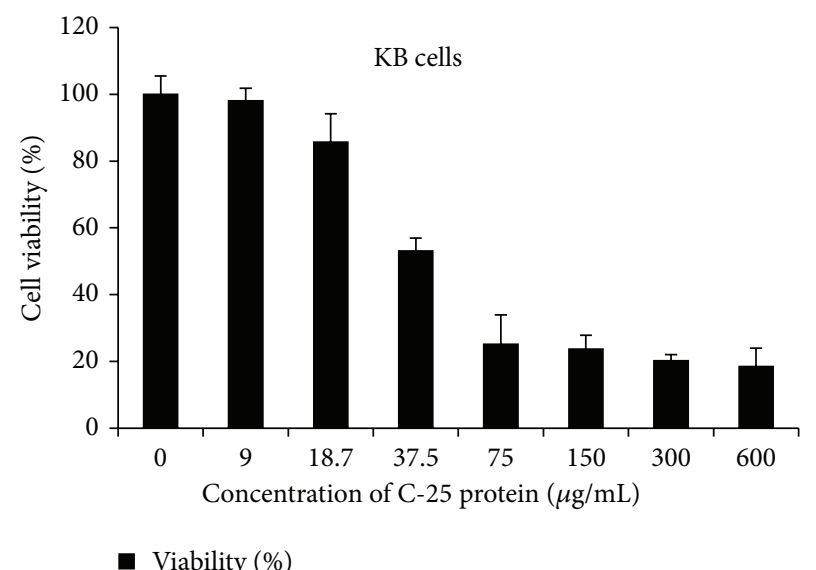

Figure 4: Cell viability of cancer cells (KB cell line) treated with different concentrations of C-25 protein.

Figures 3(c) and 3(d) showed irregular cell surface, cell wall disruption, and cytoplasmic leakage at different times, 30 and $60 \mathrm{~min}$., respectively.

3.6. Cytotoxicity. The cytotoxicity of the $\mathrm{C}-25$ against $\mathrm{KB}$ cell line was investigated using MTT assay. $50 \%$ of KB cell survival

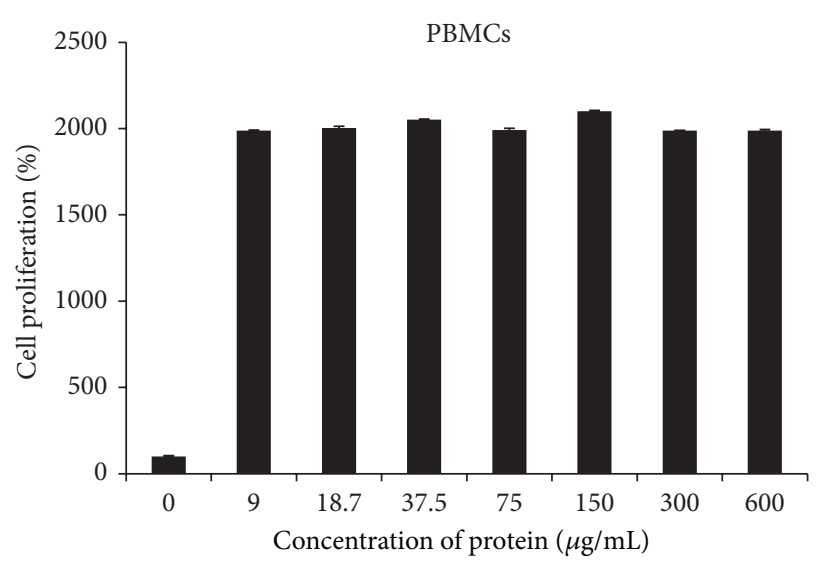

FIGURE 5: Cell proliferation of normal PBMCs at different concentrations of C-25 protein.

was reduced by treating with $37.5 \mu \mathrm{g} / \mathrm{mL}\left(\mathrm{IC}_{50}\right)$ of C-25. At $75 \mu \mathrm{g} / \mathrm{mL}$, it significantly inhibited the survival of KB cells in $48 \mathrm{~h}$ incubation period (Figure 4 ).

In the case of normal mammalian cells (PBMCs), no toxic effect of C-25 lectin was found even at higher concentration of $600 \mu \mathrm{g} / \mathrm{mL}$ but it enhanced the normal cell proliferation 


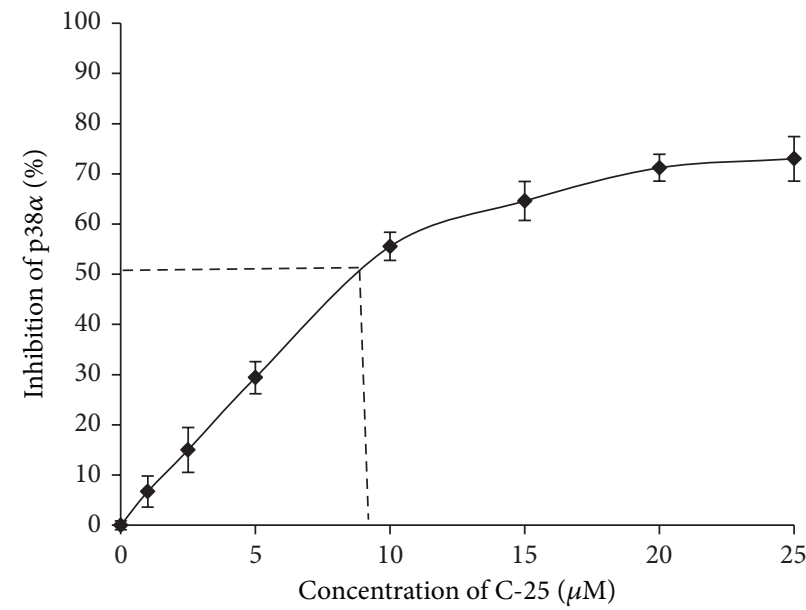

(a)

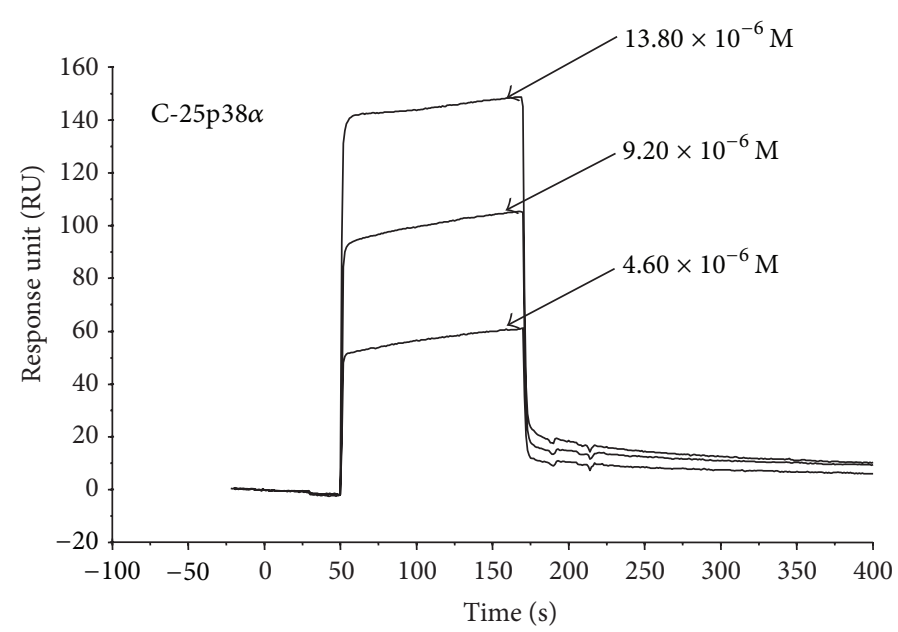

(b)

FIGURE 6: Inhibition assay: (a) \% inhibition of $\mathrm{p} 38 \alpha$ with increasing concentration of C-25; (b) Sensorgram showing the binding interaction of p38 $\alpha$ with increasing concentrations of C-25.

(Figure 5). Hence, it indicates that the C-25 inhibits the proliferation of cancer cells selectively.

3.7. Kinetic Analysis of C-25 with $p 38 \alpha$ MAP Kinase. p38 $\alpha$ is a cell signaling molecule and is reported to be overexpressed in oral cancer [13]. Hence, binding study of C-25 was performed with recombinant p38 $\alpha$ MAP kinase (mitogen activated protein kinase) using both ELISA and BIAcore to ensure the antiproliferative activity.

3.7.1. By ELISA. The pure $\mathrm{p} 38 \alpha$ was incubated with C-25 and the phosphorylation activity of $\mathrm{p} 38 \alpha$ was tested in the presence of ATP. It inhibited p $38 \alpha$ by competing with ATP. Thus, it prevented the phosphorylation of the activated transcription factor-2 (ATF-2). The $\mathrm{IC}_{50}$ value of $\mathrm{C}-25$ was found to be $7.9 \mu \mathrm{M}$ against the pure $\mathrm{p} 38 \alpha$ protein (Figure $6(\mathrm{a})$ ).

3.7.2. By SPR Technology. The specific bindings of C-25 were determined in the form of binding capacity on to immobilized p $38 \alpha$ protein. The change in RU (resonance unit) with different concentrations denoted the change in bound mass on the sensor chip with time giving the KD value of $C$ $25,2.69 \times 10^{-7} \mathrm{M}$. The sensorgram in Figure 6(b) shows the binding of varying concentrations of C-25 over p38 $\alpha$.

Hence, by ELISA and SPR it can be revealed that C- 25 can inhibit the activity of $\mathrm{p} 38 \alpha$.

\section{Discussion}

Cicer arietinum has been used in many traditional medical purposes. C-25 protein isolated from Cicer arietinum exhibited strong antifungal activities against human pathogens: Candida krusei, Candida tropicalis, and Candida parapsilosis of MIC values $1.56-12.5 \mu \mathrm{g} / \mathrm{L}$. It also inhibits the growth of fungal strains which are resistant and susceptible-dose dependent to fluconazole. The MIC of C-25 on fungal growth was comparable to the antifungal lectins of other leguminous plants. Though the exact mode of action of lectin on fungal growth is not clearly known it was previously observed by SEM that lectin disrupted the cell wall and resulted in leakage of cytoplasm [14]. In the present investigation, C-25 also acts primarily on the cell wall of Candida species, by disrupting the cell wall and distorting the cellular morphologies.

Lectins are widely used in agriculture as antimicrobials and pesticides. Some lectins have been isolated from plants having antifungal properties in plant pathogens [15-22]. The present study reveals the isolation of lectin (C-25) of molecular weight $25 \mathrm{kDa}$ from Cicer arietinum. The C-25 was found to be monomer as the molecular mass obtained by SDS-PAGE analysis was the same in both reducing and nonreducing conditions. N-terminal sequence of the C-25 protein had some amino acids sequence similarity with the previously isolated lectin from other plant sources having a different molecular weight. The database search using BLAST indicated that the sequence showed $100 \%$ homology with lectins of Pisum sativum, Lathyrus sativus, and Cicer arietinum. The characteristic properties of lectin isolated previously from Cicer arietinum (PDB 3S18) are not reported. The present study isolated lectin C-25 from chickpea (Cicer arietinum) and reported the biological properties. Many sugar binding lectins from seeds of leguminous plants are well characterised and offer many biological functions. The hemagglutination activity of C-25 was inhibited by $\mathrm{N}$-acetyl-D-galactosamine and showed to be $\mathrm{N}$-acetyl-D-galactosamine-specific protein.

It is well recognized that lectins exhibit an anticancer activity. The intensive cancer research is going on the basis of different cell surface sugar moieties of cancerous cells [23]. The different mode of cytotoxic effect was observed by different lectin. Lectin isolated from different sources differentially inhibited the type of cancer cell proliferation like leukemia L1210 cells [24], HeLa and FemX cells [25], breast cancer MCF7 cells and hepatoma HepG2 cells [26], hepatoma (HepG2) cells $[27,28]$, and KB cell line. Earlier 
studies have reported the inhibitory effect of ethanol/acetone extract from Cicer arietinum on the proliferation of Caco2 cells [29] as well as the antiproliferative effect of Cicer arietinum PIC on breast and prostate cancer cell lines [30]. In the present study, MTT assay demonstrated a significant cell death of oral cancer cell line (KB cell line) treated with $\mathrm{C}-25$. The inhibition of $\mathrm{KB}$ cell line viability with C-25 was concentration dependent. But even at high doses it is nontoxic to normal mammalian PBMCs; rather it induces proliferation of normal cells which is the characteristic of many plant lectins [31].

This lectin also inhibits the p38 $\alpha$ MAP kinase in presence of substrate (ATP) and showed binding affinity with p38 $\alpha$. The p38 $\alpha$ plays a central role in the production of inflammatory cytokines IL- $1 \beta$, TNF- $\alpha$, and IL- 6 . The overproduction of these cytokines causes tumor growth. There is an evidence of overexpression of $\mathrm{p} 38 \alpha$ in oral cancer patients and its declination after treatment [13]. Hence, it may be assumed that C-25 inhibits the oral cancer cell lines (KB cells) growth by targeting p $38 \alpha$ MAP kinase.

It can be concluded that a lectin C-25 isolated from Cicer arietinum possessed carbohydrate specificity and antifungal and antiproliferative activity. Hence, C-25 only after in vivo studies can be considered to be an effective bioactive compound.

\section{Conflict of Interests}

The authors declare that there is no conflict of interests regarding the publication of this paper.

\section{Acknowledgments}

The authors acknowledge Indian Council of Medical Research, Government of India, New Delhi, India, for providing funds for the consumable items and fellowship to Suresh Kumar and National Institute of Immunology, New Delhi, India, for performing N-terminal sequencing of C-25 protein.

\section{References}

[1] X. Y. Ye, T. B. Ng, and P. F. Rao, "Cicerin and arietin, novel chickpea peptides with different antifungal potencies," Peptides, vol. 23, no. 5, pp. 817-822, 2002.

[2] D. Zhang and F. T. Halaweish, "Isolation and identification of foetidissimin: a novel ribosome-inactivating protein from Cucurbita foetidissima," Plant Science, vol. 164, no. 3, pp. 387393, 2003.

[3] B. Liu, H.-J. Bian, and J.-K. Bao, "Plant lectins: potential antineoplastic drugs from bench to clinic," Cancer Letters, vol. 287, no. 1, pp. 1-12, 2010.

[4] H.-Y. Lei and C.-P. Chang, "Lectin of Concanavalin A as an antihepatoma therapeutic agent," Journal of Biomedical Science, vol. 16, no. 1, article 10, 2009.

[5] I. A. Qureshi, P. Dash, P. S. Srivastava, and K. R. Koundal, "Purification and characterization of an N-acetyl-D-galactosamine-specific lectin from seeds of chickpea (Cicer arietinum L.)," Phytochemical Analysis, vol. 17, no. 5, pp. 350-356, 2006.

[6] U. K. Laemmli and M. Favre, "Maturation of the head of bacteriophage T4. I. DNA packaging events," Journal of Molecular Biology, vol. 80, no. 4, pp. 575-599, 1973.

[7] T. Yeasmin, M. A. K. T. Md Abul Kashem Tang, A. Razzaque, and N. Absar, "Purification and characterization of three galactose specific lectins from mulberry seeds (Morus sp.)," European Journal of Biochemistry, vol. 268, no. 23, pp. 6005-6010, 2001.

[8] Clinical and laboratory Standards Institute, Reference Method for Broth Dilution Antifungal Susceptibility Testing of Yeasts, Approved Standard M27-A3, Clinical and Laboratory Standards Institute, Wayne, Penn, USA, 3rd ed edition, 2008.

[9] N. Kondori, L. Baltzer, G. T. Dolphin, and I. Mattsby-Baltzer, "Fungicidal activity of human lactoferrin-derived peptides based on the antimicrobial $\alpha \beta$ region," International Journal of Antimicrobial Agents, vol. 37, no. 1, pp. 51-57, 2011.

[10] N. Sitaram, K. P. Sai, S. Singh, K. Sankaran, and R. Nagaraj, "Structure-function relationship studies on the frog skin antimicrobial peptide Tigerinin 1: design of analogs with improved activity and their action on clinical bacterial isolates," Antimicrobial Agents and Chemotherapy, vol. 46, no. 7, pp. 22792283, 2002.

[11] T. Mosmann, "Rapid colorimetric assay for cellular growth and survival: application to proliferation and cytotoxicity assays," Journal of Immunological Methods, vol. 65, no. 1-2, pp. 55-63, 1983.

[12] A. Bøyum, "Isolation of lymphocytes, granulocytes and macrophages," Scandinavian Journal of Immunology, vol. 5, pp. 9-15, 1976.

[13] K. Gill, B. K. Mohanti, M. S. Ashraf, A. K. Singh, and S. Dey, "Quantification of p38 $\alpha$ MAP kinase: a prognostic marker in HNSCC with respect to radiation therapy," Clinica Chimica Acta, vol. 413, no. 1-2, pp. 219-225, 2012.

[14] S. Y. Wang, J. H. Wu, T. B. Ng, X. Y. Ye, and P. F. Rao, "A nonspecific lipid transfer protein with antifungal and antibacterial activities from the mung bean," Peptides, vol. 25, no. 8, pp. 12351242, 2004.

[15] J. Ciopraga, O. Gozia, R. Tudor, L. Brezuica, and R. J. Doyle, "Fusarium sp. growth inhibition by wheat germ agglutinin," Biochimica et Biophysica Acta, vol. 1428, no. 2-3, pp. 424-432, 1999.

[16] M. P. Does, P. M. Houterman, H. L. Dekker, and B. J. C. Cornelissen, "Processing, targeting, and antifungal activity of stinging nettle agglutinin in transgenic tobacco," Plant Physiology, vol. 120, no. 2, pp. 421-431, 1999.

[17] X. Y. Ye, T. B. Ng, P. W. K. Tsang, and J. Wang, "Isolation of a homodimeric lectin with antifungal and antiviral activities from red kidney bean (Phaseolus vulgaris) seeds," Journal of Protein Chemistry, vol. 20, no. 5, pp. 367-375, 2001.

[18] O. Gozia, J. Ciopraga, T. Bentai et al., "Antifungal properties of lectin and new chitinases from potato tuber," FEBS Letters, vol. 37, pp. 245-249, 1995.

[19] L. Xia and T. B. Ng, "An antifungal protein from flageolet beans," Peptides, vol. 26, no. 12, pp. 2397-2403, 2005.

[20] G. Zhang, J. Sun, H. Wang, and T. B. Ng, "First isolation and characterization of a novel lectin with potent antitumor activity from a Russula mushroom," Phytomedicine, vol. 17, no. 10, pp. 775-781, 2010.

[21] X. Wang and G. J. Bunkers, "Potent heterologous antifungal proteins from cheeseweed (Malva parviflora)," Biochemical and 
Biophysical Research Communications, vol. 279, no. 2, pp. 669$673,2000$.

[22] S. Charungchitrak, A. Petsom, P. Sangvanich, and A. Karnchanatat, "Antifungal and antibacterial activities of lectin from the seeds of Archidendron jiringa Nielsen," Food Chemistry, vol. 126, no. 3, pp. 1025-1032, 2011.

[23] N. Sharon, "Lectins: past, present and future," Biochemical Society Transactions, vol. 36, no. 6, pp. 1457-1460, 2008.

[24] T. B. Ng, P. H. K. Ngai, and L. Xia, "An agglutinin with mitogenic and antiproliferative activities from the mushroom Flammulina velutipes," Mycologia, vol. 98, no. 2, pp. 167-171, 2006.

[25] I. Pajic, Z. Kljajic, N. Dogovic, D. Sladic, Z. Juranic, and M. J. Gasic, "A novel lectin from the sponge Haliclona cratera: isolation, characterization and biological activity," Comparative Biochemistry and Physiology Part C, vol. 132, no. 2, pp. 213-221, 2002.

[26] P. Lin, X. Ye, and T. Ng, "Purification of melibiose-binding lectins from two cultivars of Chinese black soybeans," Acta Biochimica et Biophysica Sinica, vol. 40, no. 12, pp. 1029-1038, 2008.

[27] Y. Li, G. Zhang, T. B. Ng, and H. Wang, "A novel lectin with antiproliferative and HIV-1 reverse transcriptase inhibitory activities from dried fruiting bodies of the monkey head mushroom hericium erinaceum," Journal of Biomedicine and Biotechnology, vol. 2010, Article ID 716515, 9 pages, 2010.

[28] S. K. Lam and T. B. Ng, "Lectins: production and practical applications," Applied Microbiology and Biotechnology, vol. 89, no. 1, pp. 45-55, 2011.

[29] J. Girón-Calle, J. Vioque, M. Del Mar Yust, J. Pedroche, M. Alaiz, and F. Millán, "Effect of chickpea aqueous extracts, organic extracts, and protein concentrates on cell proliferation," Journal of Medicinal Food, vol. 7, no. 2, pp. 122-129, 2004.

[30] P. J. Magee, R. O. Apenten, M. J. Mc Cann, C. I. Gill, and I. R. Rowland, "Chickpea (Cicer arietinum) and other plant plant derived protease inhibitor concentrates inhibit breast and prostate cancer cell proliferation in vitro," Nutrition and Cancer, vol. 64, no. 5, pp. 741-748, 2012.

[31] L. Regis, M. Ribeiro, V. Vale et al., "Effect of different lectins on the proliferation of goat peripheral blood mononuclear cells," Small Ruminant Research, vol. 46, no. 1, pp. 71-73, 2002. 

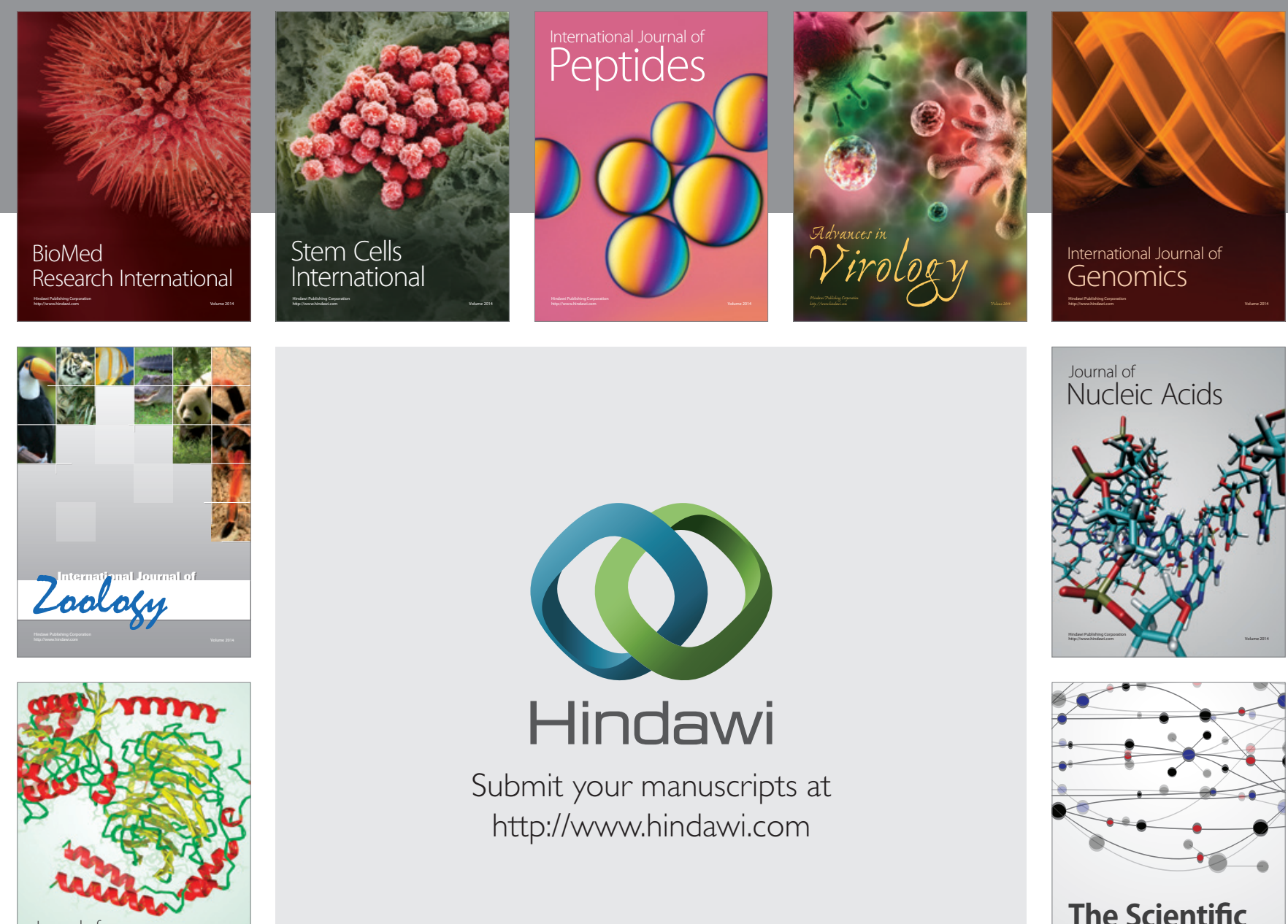

Submit your manuscripts at

http://www.hindawi.com

Journal of
Signal Transduction
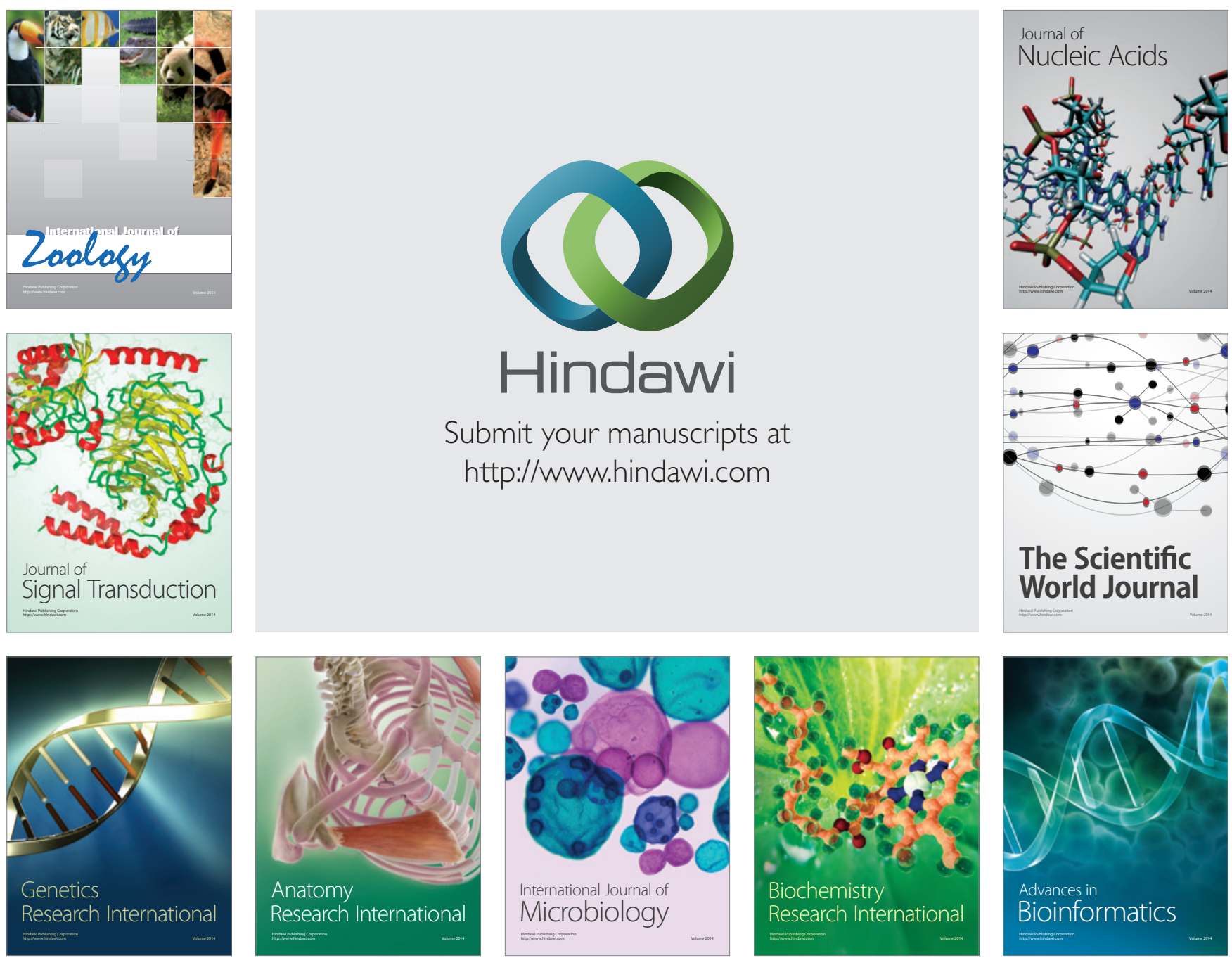

The Scientific World Journal
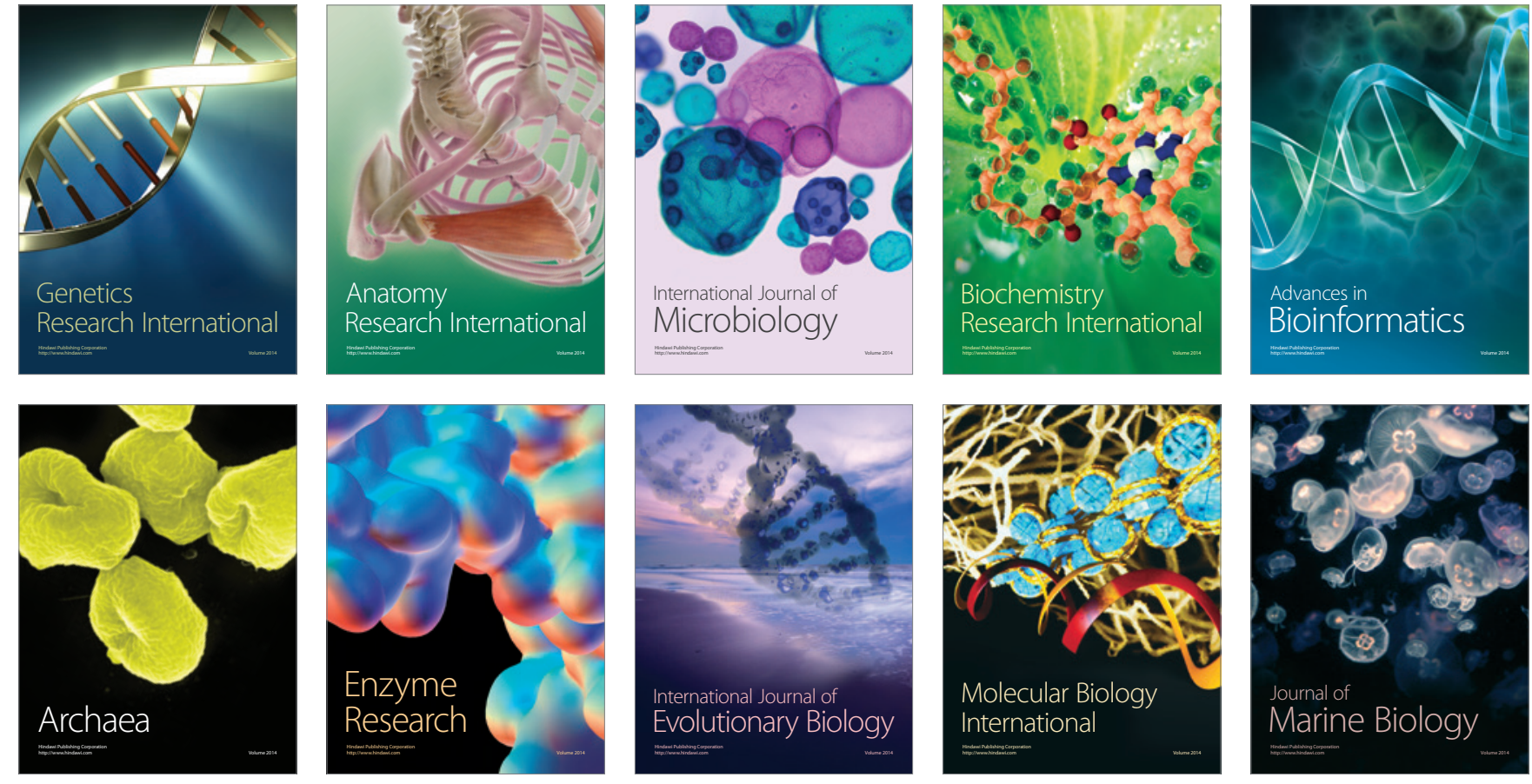